\title{
Mohammad Ali Amir-Moezzi, Hasan Ansari. Note bibliographique sur le Kitāb Sulaym b. Qays, le plus ancien ouvrage shi'ite existant
}

\section{Mathieu Terrier}

\section{(2) OpenEdition}

1 Journals

Édition électronique

URL : http://journals.openedition.org/abstractairanica/40275

DOI : 10.4000/abstractairanica.40275

ISSN : 1961-960X

Éditeur :

CNRS (UMR 7528 Mondes iraniens et indiens), Éditions de l'IFRI

Édition imprimée

Date de publication : 1 décembre 2013

ISSN : 0240-8910

Référence électronique

Mathieu Terrier, « Mohammad Ali Amir-Moezzi, Hasan Ansari. Note bibliographique sur le Kitāb Sulaym b. Qays, le plus ancien ouvrage shi'ite existant », Abstracta Iranica [En ligne], Volume 32-33 | 2013, document 359, mis en ligne le 01 juillet 2016, consulté le 26 septembre 2020. URL : http:// journals.openedition.org/abstractairanica/40275; DOI : https://doi.org/10.4000/abstractairanica 40275

Ce document a été généré automatiquement le 26 septembre 2020.

Tous droits réservés 


\title{
Mohammad Ali Amir-Moezzi, Hasan Ansari. Note bibliographique sur le Kitāb Sulaym b. Qays, le plus ancien ouvrage shi ite existant
}

\author{
Mathieu Terrier
}

\section{RÉFÉRENCE}

Mohammad Ali Amir-Moezzi, Hasan Ansari. « Note bibliographique sur le Kitāb Sulaym b. Qays, le plus ancien ouvrage shi' ite existant », in : Mohammad-Ali Amir-Moezzi, Meir M. Bar-Asher, Simon Hopkins, éds., Le shīisme imāmite quarante ans après. Hommage à Etan Kohlberg. Turnhout, Brepols, 2009, p. 33-48.

1 Poursuivant son défrichement de la littérature chiite primitive, M. A. Amir-Moezzi présente le «livre de Sulaym », attribué par la tradition à un personnage du début de l'islam, disciple du premier imām et contemporain des quatre suivants. Si l'ouvrage est sans doute pseudépigraphique et a subi des ajouts ultérieurs, l'A. établit qu'il possède un noyau primitif constituant le plus ancien livre chiite parvenu jusqu'à nous. Comme l'indique son autre titre, le "Livre de la Saqiifa ", il porte sur les évènements ayant suivi la mort du Prophète, à commencer par l'élection du premier calife sous le préau public de la Saqīfa. Le récit fait état d'un véritable complot ourdi par Abū Bakr et 'Umar afin d'usurper les droits sacrés de 'Alī b. Abī Ṭālib et de s'emparer du pouvoir, complot dont l'exécution s'accompagne de violences inouïes sur la famille du Prophète. Cette version de l'histoire du proto-islam a fini par devenir une source d'inquiétude pour les Chiites eux-mêmes, exposés aux persécutions du pouvoir sunnite. Prenant alors un caractère secret, sa trame a donné naissance à la première forme d'herméneutique proprement chiite du Coran, celle du " commentaire personnalisé ». Cet article se trouve développé et prolongé par d'autres études monographiques sur la question du Coran chez les 
Chiites dans le tout dernier ouvrage de M. A. Amir-Moezzi, Le Coran silencieux et le Coran parlant (Paris, Editions du CNRS, 2011).

\section{AUTEURS}

\section{MATHIEU TERRIER}

Paris 